\title{
Optimization of the preparation of oligoperoxide films on an amorphous metallic surface $\mathrm{Fe}-(\mathrm{Me})-\mathrm{Si}-\mathrm{B}$
}

\author{
Oksana HERTSYK ${ }^{1}$, Myroslava KOVBUZ ${ }^{1}$, Olga YEZERSKA ${ }^{2}$, Lidiya BEDNARSKA $^{1}$, Yaroslav KHIMYAK ${ }^{3}$ \\ ${ }^{1}$ Department of Physical and Colloidal Chemistry, Ivan Franko National University of Lviv, \\ Kyryla i Mefodiya St. 6, 79005 Lviv, Ukraine \\ ${ }^{2}$ Department of Adhesive Bonding Technology and Surfaces, Fraunhofer Institut für Fertigungstechnik und \\ Angewandte Materialforschung, Wiener St. 12, D-28359 Bremen, Germany \\ ${ }^{3}$ Department of Chemistry, University of Liverpool, Liverpool L69 7ZD, United Kingdom \\ * Contacting author. Tel.: +380-32-2600397; e-mail: o_hertsyk@yahoo.com
}

Received February 26, 2008; accepted June 26, 2009; available on-line November 16, 2009

Investigations of the corrosion resistance of protecting oligoperoxide coatings on magnetic soft amorphous metallic alloys constitute an important task for technical applications these materials. The influence of the oligoperoxide concentration, chemical composition of the amorphous alloy $\left(\mathrm{Fe}_{78.5} \mathrm{Ni}_{1.0} \mathrm{Mo}_{0.5} \mathrm{Si}_{6.0} \mathbf{B}_{14.0}\right.$ or $\left.\mathrm{Fe}_{73.1} \mathrm{Cu}_{1.0} \mathrm{Nb}_{3.0} \mathrm{Si}_{15.5} \mathrm{~B}_{7.4}\right)$ and the time of film creation on the stability of the coating was investigated by electrochemical impedance spectroscopy (EIS), potentiometry, electron microscopy, and measurements of the wetting angle. Oligoperoxides based on vinyl acetate, 2-tert-butylperoxy-2-methyl-5-hexene-3-yne and maleic anhydride were used in the experiments. The effect of the factors mentioned above on the film formation process on the surface of amorphous alloys is discussed.

Amorphous metallic alloys / Electrochemical impedance spectroscopy / Potentiometry / Oligoperoxide

\section{Оптимізація одержання олігопероксидних плівок на поверхні аморфних металевих сплавів Fe-(Me)-Si-B}

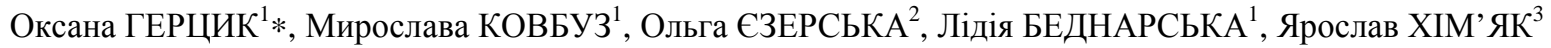 \\ ${ }^{1}$ Кафедра фізичної та колоїдної хімії, Львівський начіональний університет імені Івана Франка, \\ вул. Кирила і Мефодія 6,79005 Львів, Украӥна \\ ${ }^{2}$ Department of Adhesive Bonding Technology and Surfaces, Fraunhofer Institut für Fertigungstechnik und \\ Angewandte Materialforschung, Wiener St. 12, D-28359 Bremen, Germany \\ ${ }^{3}$ Department of Chemistry, University of Liverpool, Liverpool L69 7ZD, United Kingdom \\ * Контактна особа. Тел.: +380-32-2600397; e-mail: o_hertsyk@yahoo.com
}

Дослідження корозійного опору захисних олігопероксидних покриттів на магнітом'яких аморфних металевих сплавах с важливим практичним завданням в технічному використанні цих матеріалів. Методом електрохімічної імпедансної спектроскопії (ЕIC), потенціометрії, вимірювання крайового кута змочування та мікрофотографії поверхні досліджено вплив концентрації олігопероксиду, елементного складу аморфних металевих сплавів $\left(\mathrm{Fe}_{78,5} \mathrm{Ni}_{1,0} \mathrm{Mo}_{0,5} \mathrm{Si}_{6,0} \mathbf{B}_{14,0}\right.$ i $\left.\mathrm{Fe}_{73,1} \mathrm{Cu}_{1,0} \mathrm{Nb}_{3,0} \mathrm{Si}_{15,5} \mathbf{B}_{7,4}\right)$ та тривалості плівкоутворення на стійкість одержаних покрить. Як плівкоутворювач використовували співполімер вініл ацетату, 2-трет.бутилперокси-2-метил-5-гексен-3-їну та малеїнового ангідриду. Зафіксовано вплив вище згаданих факторів на процеси плівкоутворення на аморфних поверхнях.

Аморфні металеві сплави / Олігопероксиди / Електрохімічна імпедансна спектроскопія / Потенціометрія 


\section{Вступ}

Систему метал-покриття-електроліт слід розглядати як електрохімічно активну систему, яка має специфічні властивості, пов'язані із наявністю на поверхні металу плівки полімерного покриття, що змінює характер дифузії реагуючих речовин $\mathrm{i}$ кінетику електрохімічних реакцій. Така система може описуватись стаціонарними потенціалами, поляризаційними характеристиками, омічним опором, ємністю, діелектричною проникністю $(\varepsilon)$ та швидкістю дифузії. Існують різні твердження щодо того, які з цих властивостей є визначальними при оцінці захисної здатності покриття [1-3]. 3 точки зору одних дослідників, головну роль відіграє адгезія, на думку інших - дифузійне обмеження, яке створене плівкою. Деякі дослідники надають великого значення високому омічному опору полімерних плівок, здатних підвищувати їх захисні властивості.

Метал із нанесеними на ньому якісними полімерними плівками набуває позитивних значень потенціалу, в порівнянні 3 непокритим металом. Якщо плівки не містять пасивуючих пігментів, механізм виникнення на металі позитивного потенціалу не мав би бути пов' язаним iз сповільненим проникненням води і кисню до металу. Оскільки спостерігається протилежне, то можливий висновок - полімерні плівки сильно сповільнюють анодні реакції іонізації металу. Такий ефект зумовлений малою проникністю іонів через плівки у порівнянні із киснем і водою [1].

Застосування аморфних металевих сплавів (АМC) на основі феруму 3 високою магнітною сприйнятливістю розширюється в нових напрямках [4-6], таких як медицина, біологія i, разом 3 тим, виникає проблема їх захисту від специфічних агресивних середовищ полімерними покриттями. При цьому відкривається також можливість застосування полімерних пероксидних покривів як антисептичних засобів, а також іммобілізаторів лікарських препаратів. 3 уваги на те, що останнім часом пробують вводити магнітні нанорозмірні часточки у діючі живі організми, виникає необхідність створення на них нешкідливих покриттів.

\section{Методика експерименту}

Моделями для дослідження служили стрічки (товщиною 25-27 мкм) аморфних металевих сплавів $\quad \mathrm{Fe}_{78,5} \mathrm{Ni}_{1,0} \mathrm{Mo}_{0,5} \mathrm{Si}_{6,0} \mathrm{~B}_{14,0} \quad$ (AMC-1) та $\mathrm{Fe}_{73,1} \mathrm{Cu}_{1,0} \mathrm{Nb}_{3,0} \mathrm{Si}_{15,5} \mathrm{~B}_{7,4}$ (AMC-2), 3 яких виготовлялися електроди для електрохімічних досліджень. Технологія виготовлення стрічок сплавів методом спінінгування розплаву на охолоджуючий елемент зумовлює відмінність елементного складу та структури між контактною (к) та зовнішньою підтверджено нами

(3) поверхнями, що та дифрактометрично [7,8]. Досліджувані об'єкти відрізняються складом елементів допантів: АMC-1 містить $\mathrm{Ni}$ та Мо, а AMC-2 - Cu i Nb. Ці елементи не тільки змінюють хімію поверхні, але й кристалічність, що підтверджують дифрактометричні дослідження (Рис. 1) [7]. АМС-1 є більш кристалічним, про що свідчить вдвічі інтенсивніший пік при $2 \theta \sim 52^{\circ} . \mathrm{Nb}$ у сплаві АMC-2 запобігає кристалізації.

Як первинний плівкоутворювач був використаний гетерофункціональний олігопероксид (ОП - вінілацетат (ВА), 2mрет.бутилперокси-2-метил-5-гексен-3-їн (ВЕП), малеїновий ангідрид (MA)), тобто ВА:ВЕП:МА=1:1:1. (Олігопероксид синтезований співробітниками кафедри органічної хімії Національного університету «Львівська політехніка» за методикою, поданою в праці [9].) Він має високу адсорбційну здатність і проявляє водночас антисептичні властивості.

Електрохімічні дослідження одержаних покриттів проводили у 0,5 М водному розчині $\mathrm{NaCl}$ при кімнатній температурі.

Змочування металевої поверхні розчинами електролітів та олігомеру досліджували вимірюванням крайового кута $(\theta)$ на межі трьох фаз: тверде тіло - рідина - газ, який залежить від молекулярних властивостей цих фаз. Крапля досліджуваного розчину наносилася на тверду поверхню, відносно якої визначали кут $\theta$. Міра змочування: $\cos \theta$.

Плівки досліджуваного олігомеру наносились на поверхню металевих пластинок способом витримування їх в попередньо виготовлених $(0,1 \div 1,0) \%$ розчинах олігопероксидів у $1,5 \mathrm{M}$

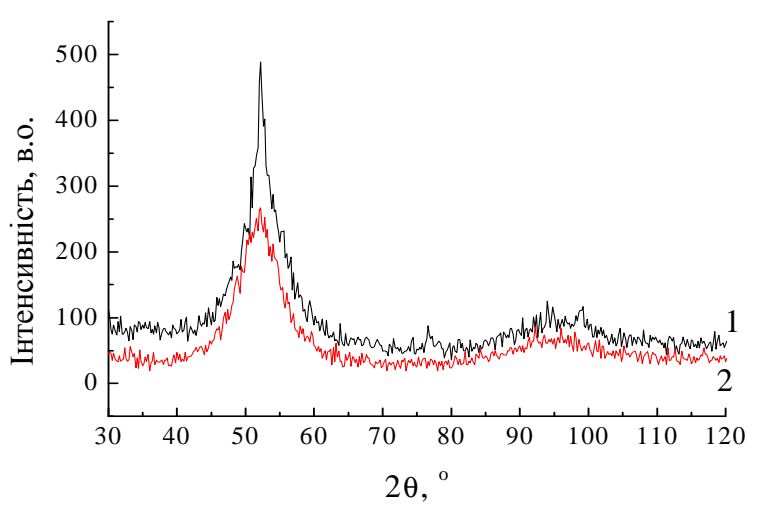

Рис. 1 Дифрактограми АMC-1 (1) та AMC-2 (2). 
Таблиця 1 Результати потенціометричних досліджень взаємодії аморфних сплавів на основі заліза 3 $0,5 \mathrm{M}$ водним розчином $\mathrm{NaCl}$.

\begin{tabular}{|c|c|c|c|c|c|c|c|c|c|}
\hline \multirow{3}{*}{ Сплав } & \multirow{3}{*}{$\begin{array}{c}\text { Поверхня } \\
\text { стрічки }\end{array}$} & \multicolumn{8}{|c|}{$C_{\mathrm{O \Pi}}, \%$} \\
\hline & & \multicolumn{2}{|c|}{0} & \multicolumn{2}{|c|}{0,1} & \multicolumn{2}{|c|}{0,5} & \multicolumn{2}{|c|}{1,0} \\
\hline & & $\begin{array}{c}E_{c}, \\
\mathrm{~B}\end{array}$ & $\begin{array}{l}t \\
\mathrm{c}\end{array}$ & $\begin{array}{c}E_{c} \\
\mathrm{~B}\end{array}$ & $\begin{array}{l}t \\
\mathrm{c}\end{array}$ & $\begin{array}{c}E_{c} \\
\mathrm{~B}\end{array}$ & $\begin{array}{l}t \\
\mathrm{c}\end{array}$ & $\begin{array}{c}E_{c}, \\
\mathrm{~B}\end{array}$ & $\begin{array}{l}t \\
\mathrm{c}\end{array}$ \\
\hline \multirow{4}{*}{ AMC-1 } & $\mathrm{K}^{*}$ & \multirow{2}{*}{$-0,635$} & \multirow{2}{*}{100} & $-0,635$ & 360 & $-0,632$ & 450 & $-0,620$ & 550 \\
\hline & $\mathrm{K}^{* *}$ & & & $-0,641$ & 300 & $-0,615$ & 600 & $-0,643$ & 240 \\
\hline & $3^{*}$ & \multirow{2}{*}{$-0,635$} & \multirow{2}{*}{530} & $-0,653$ & 500 & $-0,642$ & 500 & $-0,632$ & 730 \\
\hline & $3^{* *}$ & & & $-0,670$ & 900 & $-0,626$ & 800 & $-0,637$ & 350 \\
\hline \multirow{4}{*}{ AMC-2 } & $\mathrm{K}^{*}$ & \multirow{2}{*}{$-0,443$} & \multirow{2}{*}{250} & $-0,415$ & 42 & $-0,375$ & 80 & $-0,441$ & 50 \\
\hline & $\mathrm{K}^{* *}$ & & & $-0,430$ & 42 & $-0,402$ & 90 & $-0,452$ & 70 \\
\hline & $3 *$ & \multirow{2}{*}{$-0,443$} & \multirow{2}{*}{500} & $-0,415$ & 50 & $-0,375$ & 220 & $-0,444$ & 100 \\
\hline & $3^{* *}$ & & & $-0,430$ & 50 & $-0,403$ & 280 & $-0,480$ & 150 \\
\hline
\end{tabular}

К* - контактна поверхня (формування плівки ОП 10 хв)

К** - контактна поверхня (формування плівки ОП $(10+10)$ хв)

$3^{*}$ - зовнішня поверхня (формування плівки ОП 10 хв)

$3^{* *}$ - зовнішня поверхня (формування плівки ОП $(10+10)$ хв)

водному амоніаку протягом 10 хв. Такі зразки i позначаються у статті як 10-хвилинні плівки («10 Хв»). Зразки позначені «10+10 хв»- це зразки, поверхні яких витримувалися у розчині 10 хв, висушувалися при $298 \mathrm{~K}$ i знову повторно витримувалися протягом 10 хв у розчині. Кінцеве висушування проводилось у всіх випадках однаково в атмосфері повітря при кімнатній

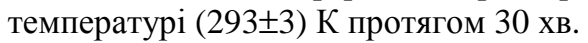

Потенціометричне дослідження активності поверхонь проводили за допомогою приладу Jaissle Potentiostat/Galvanostat IMP 88PC-R в гальванічному елементі типу: АМС-електрод | $0,5 \mathrm{M}$ водний $\mathrm{NaCl} \mid \mathrm{Ag} / \mathrm{AgCl} / \mathrm{KCl}$. Початкове значення $\left(E_{o}\right)$ та час $(t)$ встановлення стаціонарного потенціалу $\left(E_{c}\right)$ визначали із часової залежності зміни потенціалу.

Подібно як потенціометрія $(E=\mathrm{f}(\tau))$ чи вольтамперометрія $(i=\mathrm{f}(E)), \quad$ електрохімічна імпедансна спектроскопія (EIC) часто використовується для оцінки швидкостей оксидновідновних процесів [10,11]. Більшість ЕIC досліджень пов'язана 3 контролем за корозією різних металевих матеріалів та з оцінкою захисту контактуючих 3 агресивним середовищем поверхонь. Суть методу імпедансної спектроскопії полягає в подачі збуджуючого синусоїдального сигналу малої амплітуди на досліджувану систему та вивченні викликаного ним сигналу-відклику на виході [12,13]. Якщо як збуджуючий сигнал використовувати напругу $V(t)=V_{o} \sin (\omega t), \quad$ а сигнал на виході фіксувати як струм $I(t)=I_{o} \sin (\omega t+\theta)$, який протікає через систему, де $V_{o}$ та $I_{o}$ - амплітуда, відповідно, напруги та струму, $\omega=2 \pi f-$ кругова частота, $\theta-$ фазовий зсув, то імпеданс $Z(\omega)$ визначається співвідношенням:
$Z(\omega)=\frac{V(t)}{I(t)}$.

Імпеданс системи, яка складається 3 електроду, покритого плівкою, може бути описана паралельною комбінацією ємності $C_{d l}$ та опору плівки $R_{c t}$, тоді

$Z_{d l}(j \omega)=\frac{R_{c t}}{1+j \omega R_{c t} C_{d l}}$.

Ємність покриття:

$C_{d l}=\varepsilon \varepsilon_{o} \frac{A}{d}$,

де $\varepsilon$ - відносна діелектрична стала, $\varepsilon_{o}$ діелектрична стала вакууму, $A$ - площа покриття і $d$ - товщина покриття.

ЕІС вимірювалися при умовах розімкнутого кола та амплітуді $20 \mathrm{MB}$.

Мікрофотографії поверхні стрічки АМС, на яку наносили плівку ОП, одержували за допомогою електронного мікроскопу МЕТАМ РB21 (збільшення - 1000 разів).

\section{Результати}

Адсорбційні шари олігопероксидів в залежності від способу їх нанесення можуть бути недостатньо стійкими $\mathrm{y}$ різних середовищах, зокрема, у еталонному агресивному розчині (водному $0,5 \mathrm{M}$ $\mathrm{NaCl}$ ), в якому звичайно проводиться тестування якості захисних покрить. Оцінка електрохімічної стійкості плівок, нанесених на поверхню аморфних сплавів на основі заліза $3(0,1 \div 1,0) \%$ водно-аміачних розчинів (Табл. 1, Рис. 2,3), показала залежність спорідненості 
O. Hertsyk et al., Optimization of the preparation of oligoperoxide films on an amorphous metallic surface ...

Таблиця 2 Величина змочування $(\cos \theta)$ поверхонь АМС водно-аміачними розчинами ОП різної концентрації.

\begin{tabular}{|c|c|c|c|c|}
\hline \multirow{2}{*}{ Сплав } & \multirow{2}{*}{$\begin{array}{c}\text { Поверхня } \\
\text { стрічки }\end{array}$} & \multicolumn{3}{|c|}{$C_{\mathrm{O \Pi}}, \%$} \\
\hline & & 0,1 & 0,5 & 1,0 \\
\hline \multirow{2}{*}{ AMC-1 } & к & 0,71 & 0,86 & 0,78 \\
\hline & 3 & 0,81 & 0,97 & 0,85 \\
\hline \multirow{2}{*}{ AMC-2 } & к & 0,74 & 0,82 & 0,82 \\
\hline & 3 & 0,80 & 0,95 & 0,88 \\
\hline
\end{tabular}

Таблиця 3 Результати досліджень EIC AMC-1 у 0,5 M NaCl, попередньо покритого плівкою 3 0,5\% водно-аміачного розчину олігопероксиду.

\begin{tabular}{c|c|c|c|c|c}
\hline $\begin{array}{c}\text { Тривалість } \\
\text { плівкоутворення, хв }\end{array}$ & $\begin{array}{c}\text { Поверхня } \\
\text { стрічки }\end{array}$ & $\begin{array}{c}R_{c t} \cdot 10^{-3}, \\
\mathrm{OM} \mathrm{cm}^{2}\end{array}$ & $\begin{array}{c}C_{d l} \cdot 10^{3}, \\
\Phi \mathrm{cm}^{-2}\end{array}$ & $\alpha$ & $r$ \\
\hline \multirow{2}{*}{10} & к & 2,37 & 1,01 & 0,77 & 50,6 \\
& 3 & 5,95 & 0,70 & 0,82 & 39,1 \\
\multirow{2}{*}{$10+10$} & к & 0,78 & 1,63 & 0,68 & 81,7 \\
& 3 & 5,80 & 0,29 & 0,77 & 14,9 \\
& к & 0,75 & 0,83 & 0,66 & 41,7 \\
\hline
\end{tabular}

Таблиця 4 Результати досліджень EIC AMC-2 у 0,5 M NaCl, попередньо покритого плівкою з 0,5\% водно-аміачного розчину олігопероксиду.

\begin{tabular}{c|c|c|c|c|c}
\hline $\begin{array}{c}\text { Тривалість } \\
\text { плівкоутворення, хв }\end{array}$ & $\begin{array}{c}\text { Поверхня } \\
\text { стрічки }\end{array}$ & $\begin{array}{c}R_{c t} 10^{-3}, \\
\text { Ом см }^{2}\end{array}$ & $\begin{array}{c}C_{d l} \cdot 10^{5}, \\
\Phi \mathrm{cm}^{-2}\end{array}$ & $\alpha$ & $r$ \\
\hline \multirow{2}{*}{10} & к & 3,18 & 5,44 & 0,81 & 2,7 \\
& 3 & 6,64 & 1,52 & 0,84 & 0,7 \\
\multirow{2}{*}{$10+10$} & к & 1,92 & 5,27 & 0,80 & 2,6 \\
& 3 & 6,15 & 1,47 & 0,85 & 0,7 \\
& к & 4,42 & 5,89 & 0,80 & 2,9 \\
\hline
\end{tabular}

плівкоутворювачів, в першу чергу, від елементного складу АМС на основі заліза й, очевидно, від ступеня кристалічності. Якщо для АМC-2 у всіх випадках покращується стійкість поверхні, тобто відбувається зсув потенціалу в анодний бік (Табл. 1), то для сплаву АMC-1, який має вищий ступінь кристалічності, стійка плівка утворюється лише з $0,5 \%$ розчину олігопероксиду [14]. Тривалість встановлення $E_{c}$ на поверхні AMC-2 без плівки на контактному боці в 5 разів більша, а на зовнішньому боці - 10 разів, ніж 3 плівкою $3 \quad 0,1 \%$ розчину ОП. Стаціонарний потенціал набуває позитивнішого значення у випадку електродів, покритих плівкою 3 0,5\% розчинів ОП.

При збільшенні концентрації ОП до 1,0\% та 10 хвилинному витримуванні кінцеве значення стаціонарного потенціалу у випадку АMC-2, як контактної так і зовнішньої поверхонь, практично, не змінюється, $E_{c}=-0,44$ В. Однак, тривалість досягнення стаціонарності на зовнішньому боці електроду зростає вдвоє (від 50 с до 100 с) (Табл. 1). У випадку АМС-1 нанесення плівки ОП з $0.1 \%$ водно-аміачного розчину не призводить до покращення захисних властивостей і збільшує тривалість встановлення $E_{c}$ на контактній поверхні електроду в три рази незалежно від тривалості формування плівки (Табл. 1). Практично, у всіх досліджуваних випадках тривалість встановлення стаціонарного потенціалу на зовнішніх поверхнях вища від контактних.

Найстійкіші плівки утворюються на поверхні даних сплавів з $0,5 \%$ водно-аміачного розчину ОП. Очевидно, із збільшенням концентрації розчину перебудовується структура адсорбційного шару та змінюється конформація адсорбованих молекул. При невеликій концентрації розчину після первинного зв'язування макромолекули в одній точці внаслідок гнучкості ланцюга та теплового руху молекул можливе збільшення числа контактів 

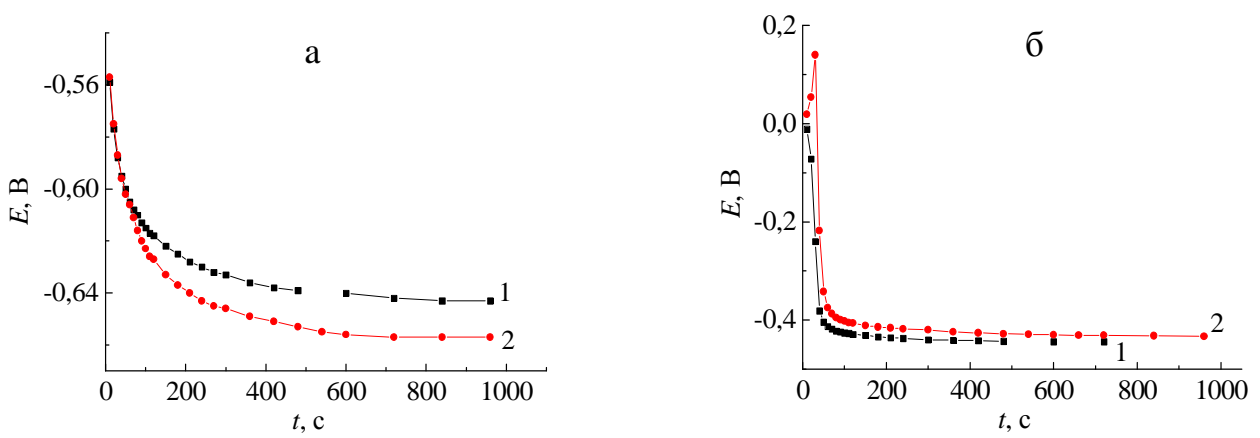

Рис. 2 Кінетика встановлення стаціонарного потенціалу на поверхні AMC-1 (а) та АMC-2 (б), покритих плівкою (0,1\% розчин ОП, формування плівки 10 хв): 1 - контактна поверхня, 2 - зовнішня поверхня.
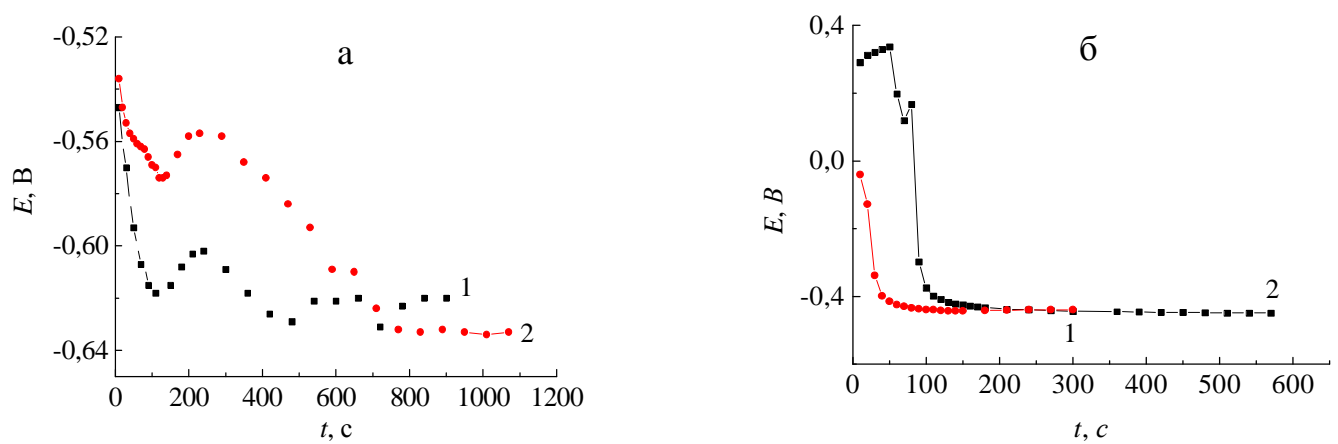

Рис. 3 Кінетика встановлення стаціонарного потенціалу на поверхні AMC-1 (а) та AMC-2 (б), покритих плівкою (1,0\% розчин ОП, формування плівки 10 хв): 1 - контактна поверхня, 2 - зовнішня поверхня.

ланцюга 3 поверхнею. При насиченні поверхні молекулами олігопероксиду, наприклад, при вищих концентраціях плівкоутворювача, адсорбційний шар утворюється згорнутими клубками і частіше $є$ псевдомономолекулярним.

В процесах отримання полімерних шаруватих матеріалів досить важливу роль відіграє змочування твердих поверхонь олігомерними i полімерними молекулами. Добре змочування $\epsilon$ необхідною умовою адгезійного сполучення i високих фізико-механічних властивостей матеріалів. У зв'язку з цим, вимірювались крайові кути змочування поверхонь АМС водноаміачними розчинами ОП різної концентрації (Табл. 2). Результати вимірювання крайового кута змочування поверхонь АМС водно-аміачними розчинами ОП різної концентрації корелюють 3 результатами потенціометричного вимірювання. Тобто, чим краще змочується поверхня сплавів розчинами, тим стійкішою є утворена плівка. Ці результати підтверджують відоме положення про те, що добре розтікання $\epsilon$ важливою умовою отримання якісних покриттів.

Модель електрохімічної корозії у методі ЕIC зображена уявно у вигляді найпростішої схеми, складеної 3 двох резисторів і конденсатора
(Рис. 4), яка $є$ задовільною при умові взаємопроникнення обох поверхневих шарів (оксидного та полімерного). Для розрахунку параметрів: опору $\left(R_{c t}\right)$, ємності $\left(C_{d l}\right)$ застосовано програми «Zview». Параметр шерхавості $(r)$ розраховано за формулою:

$r=\frac{C}{20 m F}$,

де $C$ - ємність плівки.

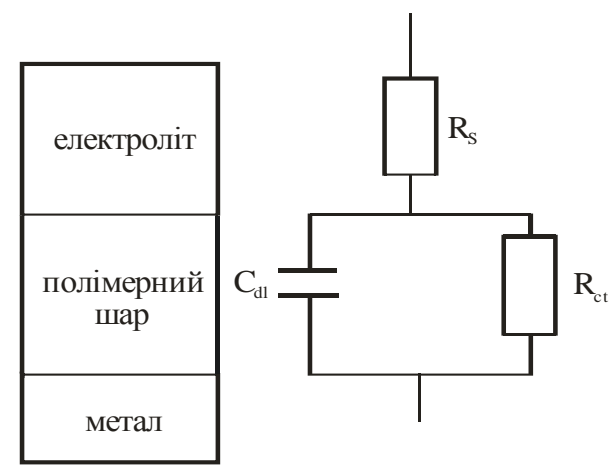

Рис. 4 Імпедансна модель бездефектного олігомерного покриття металевої поверхні в контакті з електролітом. 

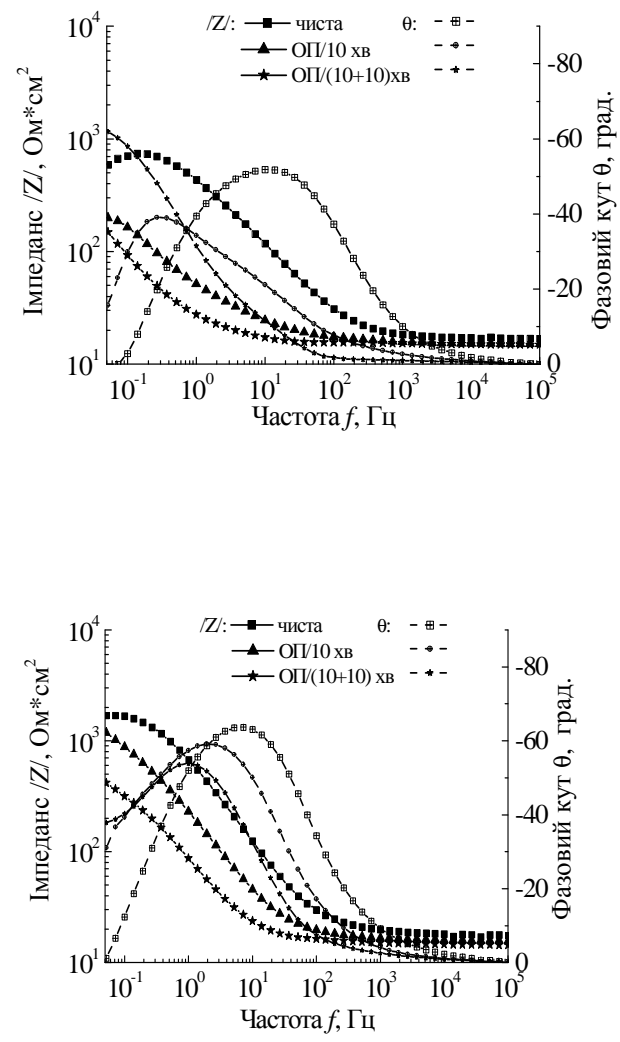

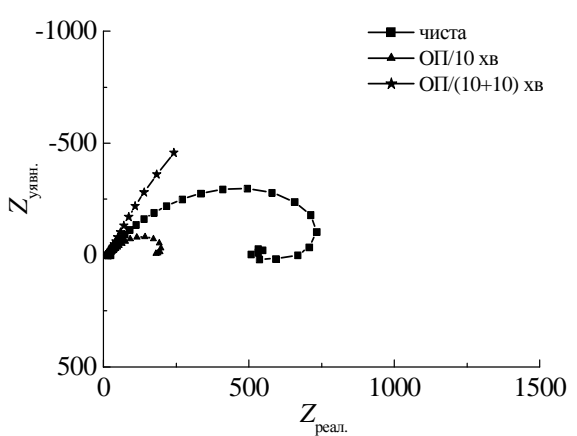

a

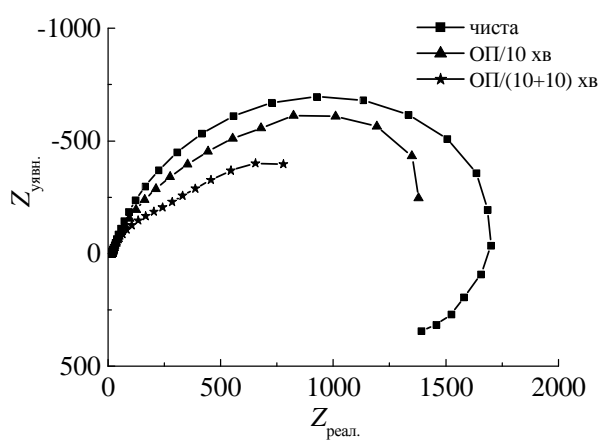

Рис. 5 Результати ЕІС досліджень контактної (а) та зовнішньої (б) поверхонь АМС-1 у 0,5 М водному розчині $\mathrm{NaCl}$, попередньо покритих плівкою ОП.

Результати досліджень методом електрохімічної імпедансної спектроскопії показали, що характеристики плівок, одержаних 3 0,5\% аміачних розчинів ОП на обох аморфних сплавах, суттєво відрізняються (Рис. 5, 6, Табл. 3,4$)$. В області частот від $10^{3} \div 10^{5}$ Гц на Боде кривих спостерігалася частотно незалежна ділянка, що описує опір електроліту. Практично від 1,0 Гц до $10^{3}$ Гц на імпедансному спектрі фіксувалось зростання імпедансу - ця область відбивала ємність особливості поверхневих шарів. У області нижчих частот, якщо знову фіксується частотно незалежна ділянка, можна спостерігати суму опорів $\left(R_{c t}+R_{s}\right)$.

Саме на основі /Z/ значень у цьому діапазоні, нижчому за 0,1 Гц, можна стверджувати, що наявність полімерних плівок на АМС по-різному змінює захисні властивості контактної і зовнішньої поверхонь. У випадку АMC-1 присутність полімерної плівки знижує опір при $\mathrm{f}=5 \cdot 10^{-2}$ Гц, як на контактній, так і на зовнішній поверхнях у порівнянні з цими поверхнями у відсутності полімерного шару (Рис. 5).

3 менш концентрованих розчинів, наприклад $0,1 \%$, адсорбційна рівновага олігомерних молекул наступає швидше від повного покриття зразка
АМС плівкою. Внаслідок збільшення вмісту ОП у адсорбаті до $1,0 \%$ ОП формуються динамічні плівки, здатні до формування багатошарових полімерних структур, що приводить до нерівномірного розподілу молекул олігомеру, утворення пор і помітного зростання шерхавості покриву $(r)$ (Табл. 3,4). Це явище добре проявляється у випадку АМС-1. Вміст у АMC-2 додатків $\mathrm{Cu}$ та $\mathrm{Nb}$ сприяє підвищенню захисних характеристик плівок олігомеру (Рис. 6). У випадку «10+10 хв» полімерна плівка навіть підвищує значення /Z/, що вказує на деяке підвищення електрохімічної стійкості контактної та зовнішньої поверхонь АMC-2.

Зовнішній вигляд олігомерних покривів на AMC-1 та AMC-2 на мікрофотографіях (Рис. 7,8) підтверджує зроблені висновки.

Внаслідок поверхневих рухів макромолекул, які проявляють високу міжмолекулярну спорідненість і утворюють надмолекулярні структури, на поверхні металу виникають незахищені адсорбційними шарами острівки 3 відкритим доступом агресивних іонів. Це i зумовлює втрату захисних властивостей плівок ОП, у першу чергу на АMC-1, внаслідок слабшої спорідненості «полімер-метал» за рахунок 
O. Hertsyk et al., Optimization of the preparation of oligoperoxide films on an amorphous metallic surface ...
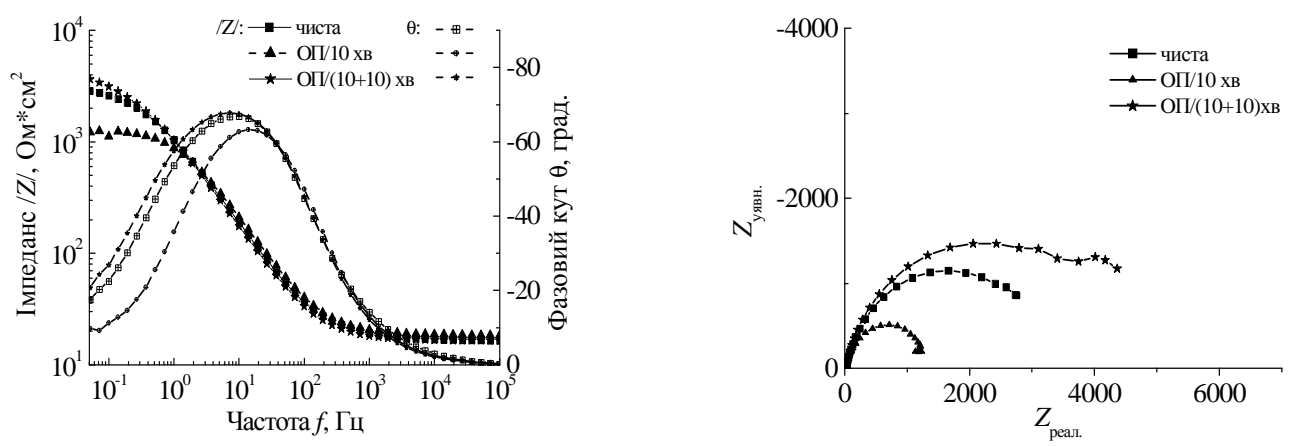

a
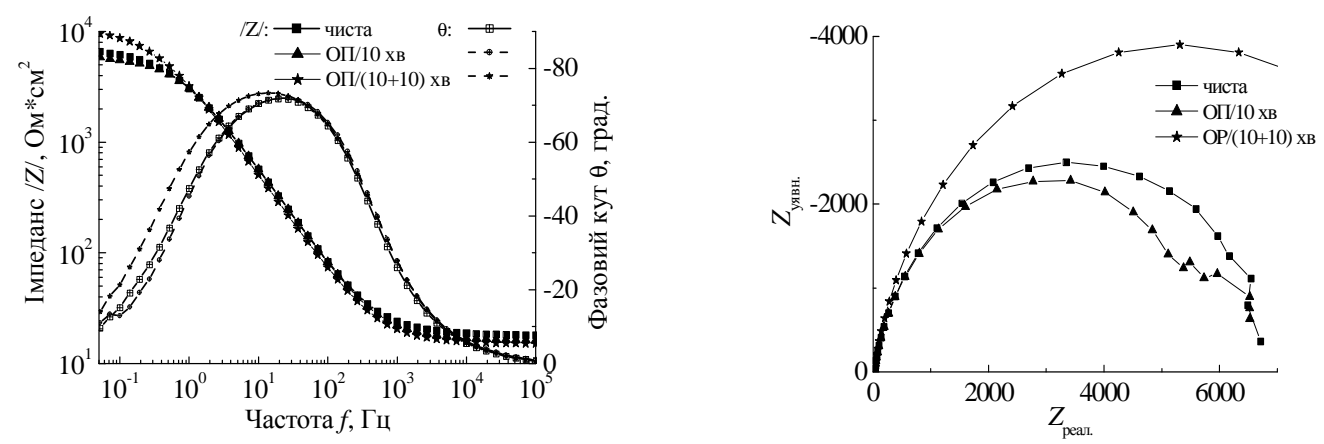

6

Рис. 6 Результати ЕІС досліджень контактної (а) та зовнішньої (б) поверхонь АМС-2 у 0,5 М водному розчині $\mathrm{NaCl}$, попередньо покритих плівкою ОП.

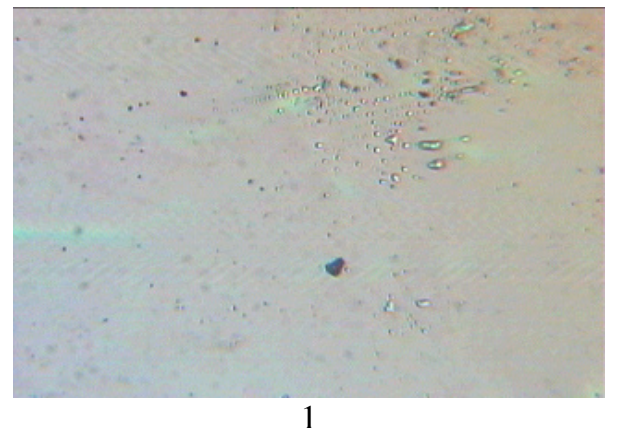

1

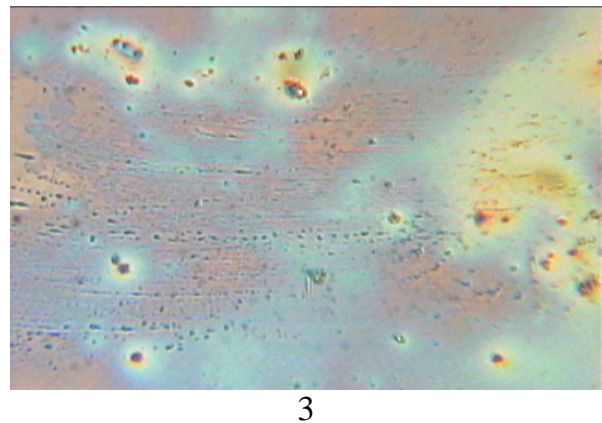

3

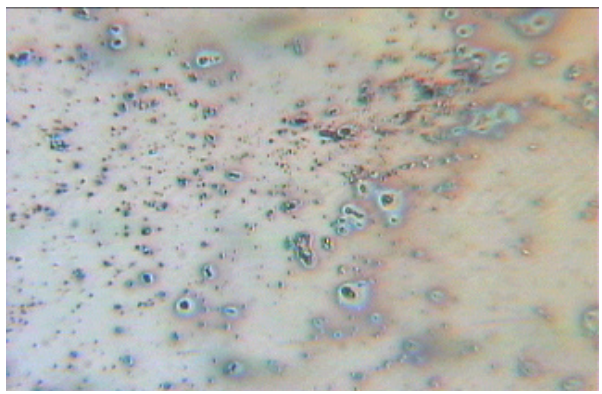

2

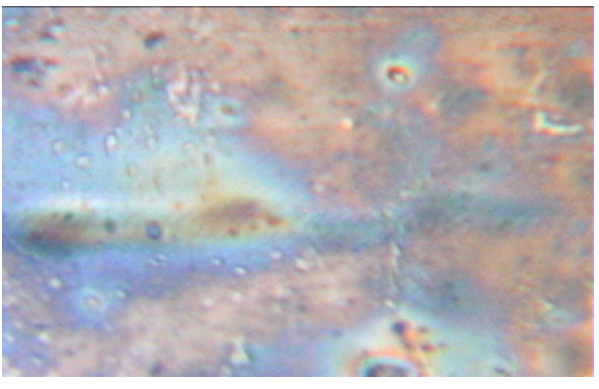

4

Рис. 7 Мікрофотографії поверхні АМС-1 (1), покритого плівками ОП різної концентрації: 0,5\% $(2,3)$, $1,0 \%$ (4) з тривалістю формування 10 хв $(2,4)$ та $(10+10)$ хв (3). 


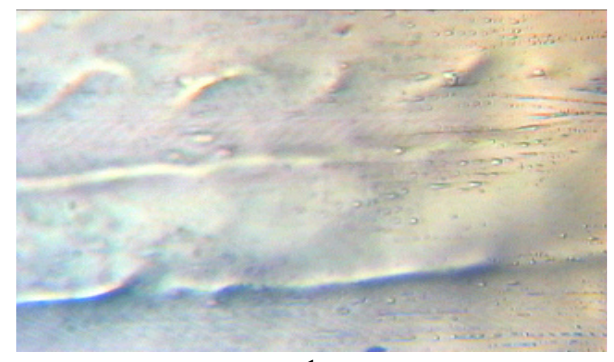

1

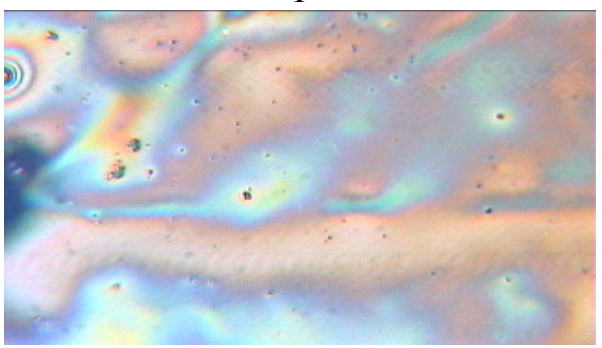

3

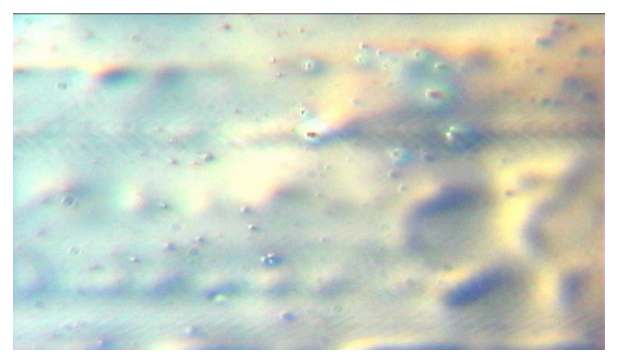

2

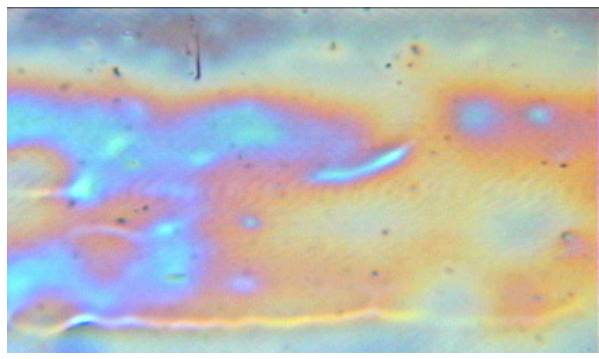

4

Рис. 8 Мікрофотографії поверхні АМС-2 (1), покритого плівками ОП різної концентрації: 0,5\% (2, 3), $1,0 \%$ (4) з тривалістю формування 10 хв $(2,4)$ та $(10+10)$ хв (3).

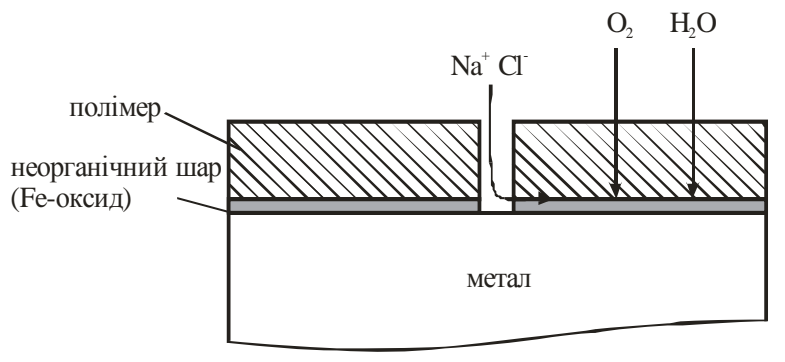

Рис. 9 Схема корозійної моделі.

елементного складу поверхні металу та вищого ступеню структурного впорядкування. Окрім цього, молекули води та кисню доволі легко дифундують через олігомерний шар (Рис. 9), який містить у структурі гідрофільні групи і помітно набрякає. Це спостерігається як у випадку нанесення олігомерних покрить 3 1,0\% водноаміачних розчинів ОП, так і внаслідок повторного витримування зразків АMC у $0,5 \%$ розчинах ОП (тобто $(10+10)$ хв).

\section{Літературні посилання}

[1] И. Розенфельд, Ф. Рубинштейн, К. Жигалова, В: Защчита металлов от коррозии лакокрасочными покрытиям, Москва, 1987, c. 57.

[2] L. Michael, Corros. Sci. 44 (2002) 2865.
[3] C. Tan, D. Blackwood, Corros. Sci. 45 (2003) 545.

[4] H. Chiriac, A. Moga, G. Iacob, C. Ostin, J. Magn. Magn. Mater. 48 (2005) 28.

[5] Д. Падерно, А. Мележик, М. Ковбуз, О. Герцик, Л. Беднарская, Труды ХII Конф. «Проблемы экологии и эксплуатации объектов энергетики», Киев, 2002, с. 147.

[6] А. Шпак, В. Маслов, В. Носенко, Наука Іннов. 1 (2005) 92.

[7] S. Mudry, L. Bednarska, Yu. Kulyk, O. Hertsyk, J. Appl. Crystallogr. 39 (2004) 289.

[8] O. Hertsyk, M. Kovbuz, A. Zaichenko, N. Mitina, Proc. X Ukr.-Pol. symp. theoretical and experimental studies of interfacial phenomena and their technological applications, Lviv, 2006, p. 113.

[9] Н.С. Мітіна, Низькотемпературні радикальні ініцііатори на основі метало комплексів гетерофункиіональних олігопероксидів, Дис. канд. хім. наук, Львів, 2003, 165 с.

[10] G. Walter, Corros. Sci. 32 (1991) 1059.

[11] G. Grundmeier, W. Schmidt, M. Stratmann, Electrochim. Acta 45 (2000) 2515.

[12] J. Mac Donald, In: Impedance Spectroscopy, Wiley, New York, 1987, p. 250.

[13] С.В. Гнеденков, С.Л. Синебрюхов, Вестн. ДВО РАН 5 (2006) 6.

[14] M. Kovbuz, O. Hertsyk, N. Mitina, Ya. Khimyak, L. Bednarska, Pol. J. Chem. 82 (2008) 93 . 